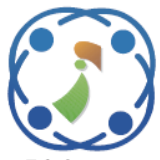

\title{
Scholarship Recipients Recommendation System Using AHP and Moora Methods
}

\author{
Anthony Anggrawan ${ }^{1 *}$ \\ Mayadi $^{1}$ \\ Christofer Satria ${ }^{2}$ \\ Lalu Ganda Rady Putra ${ }^{1}$ \\ ${ }^{1}$ Department of Computer Science, Bumigora University, Mataram, Indonesia \\ ${ }^{2}$ Department of Visual Communication Design, Bumigora University, Mataram, Indonesia \\ * Corresponding author’s Email: anthony.anggrawan@universitasbumigora.ac.id
}

\begin{abstract}
Providing scholarships to students is an important action in helping students succeed in their studies. The scholarship recipients are students who meet the specified criteria. However, it is not easy to decide which scholarship recipients are genuinely eligible to receive scholarships, especially if the selection process for prospective scholarship recipients is done manually. Many prospective scholarship recipients must be selected, and more than one criterion is required. That is why it is not surprising that awarding scholarships to selected candidates takes a long time and the accuracy of the results is dubious. It means there needs to be a system that can assist in choosing prospective students who meet the criteria for the best requirements as scholarship recipients. Therefore, the purpose of this research is to build an application system that can provide recommendations for eligible candidates for scholarship recipients based on consideration of the criteria possessed by prospective scholarship recipients. This research method is an experimental study using a combination of the Analytical Hierarchy Process (AHP) and the Multi-Objective Optimization Method by Ratio Analysis (Moora) method to rank scholarship recipients. The study results indicate that using an application system integrated into the database in recommending prospective scholarship recipients according to the desired conditions is more accurate using a combination of AHP and Moora methods (up to 94.07\%) than using only one Moora method (which is only $89.62 \%$ ). This means that the selection of scholarship recipients according to the desired qualifications using the AHP method for weighting and the Moora method for ranking is a combination of methods that have relatively more reliable accuracy.
\end{abstract}

Keywords: Scholarship, Recommendation, AHP, Moora, Decision making.

\section{Introduction}

As has been emphasized by previous research, in higher education, not only pay attention to the approach or method of education but also other factors that determine the success of schooling [1]; it turns out that one of the other factors is the cost of education. Recently, education payments have continued to increase significantly every year [2]. It becomes a stumbling block for low-income families to finance their children's studies due to their inability to pay the tuition fees. Therefore, higher education fees for the poor have been a significant issue in some countries [3]. It means financial support in education through scholarships to students in tertiary institutions is vital in helping students learn during the study period $[4,5]$. Scholarships are financing that does not come from own funds or parents but are provided by the government, private companies, universities, and educational institutions to help to increase the capacity of human resources through education. Scholarships are awarded to students based on classification, quality, and competence. Thus, scholarships facilitate education just for eligible students [5]. It means, providing scholarships for students is a solution that can help finance lowincome families [5]. What's more, the scholarship proves to help students study success [6]. Scholarships for students are generally in the form of tuition fees due to students' poor economic background and because of the outstanding academic achievements of students $[6,5]$. 
Decision-making is not an easy task because the decisions impact the results obtained [7]. Difficulties in making decisions are frequent because decisionmakers must consider criteria [8]. Likewise, selecting scholarship recipients is not easy because of many scholarship recipients [9]. Especially if the selection process for prospective scholarship recipients is still manual and the criteria for receiving scholarships are more than one criterion. Processing of scholarship recipients takes a long time, and errors often occur due to inaccuracy [5]. It means there needs to be a system that can assist in selecting prospective students who meet the criteria for the best requirements as scholarship recipients. Therefore, the purpose of this study is to build a system that can provide recommendations for eligible candidates for scholarship recipients based on consideration of the criteria possessed by prospective scholarship recipients. This study uses a combination of Moora and AHP methods to select student scholarship recipients.

AHP is very popular for its use by scientific researchers and decision-makers [10]; because AHP is a valuable method in solving problems effectively and efficiently [11]. AHP is a method that can assist in making decisions on a problem even though it has multiple criteria [12, 13]. Furthermore, AHP is effective in helping solve complex and unstructured problems [12]. In other words, the AHP method can optimize decision-making very effectively when faced with complex issues involving qualitative and quantitative data, with several criteria being considered in decision-making [14]. Therefore, AHP is very dominantly used to calculate the weight of criteria and alternatives $[15,10]$.

Although several decision-making methods exist, Moora is a computationally easy method to make the most appropriate decision [16] and more straightforward to calculate than other decisionmaking methods [17]. Moora is a multi-objective (multi-attribute or multi-criteria) optimization method [18]. Optimization with the Moora method considers both favorable and unfavorable criteria in ranking the available alternative choices [15]. While referring to the opinion of Mandal and Sarkar (2012), the method Moora is the best method compared to other methods [19]. Moora is a method that can perform a more precise ranking without being influenced by the weight of the problem criteria and the normalization procedure achieved [15].

In this study, the AHP method is utilized to ormalize the weights or find the weight values for each criterion. In addition to finding the weights, the AHP method will also test the consistent level of the weights; if the weights are consistent, then the weight values can be said to be correct. In contrast, the Moora method is utilized for the ranking process, where this method will use the weights obtained from the AHP method. There are six conditions or criteria used as the basis by the system to determine the most appropriate candidate to receive the scholarship in this study.

Some of the latest related works conducted by previous studies are as follows:

Russo \& Camanho (2015) conducted a systematic literature review of applying the AHP method to determine the decisions made from the prerequisite criteria of several selected problems. The difference between the previous research and the research in this article is that the previous research focused on using the AHP method to make decisions on various issues unrelated to student scholarships. In contrast, the research in this article focused on using the AHP method and the Moora method in making decisions for prospective scholarship recipients. College student.

Jibrin et al. (2016) built an application program that allows prospective students to apply as scholarship recipients using the Hypertext preprocessor (PHP) programming language and MySQL database. The similarity of this previous research with the research in this article is that they both build application programs with programming languages and use MySQL databases. The difference is in the previous study using the PHP programming language, while in this article, the study uses the VB.Net programming language. Another difference is that the previous research only built an application program to register prospective scholarship recipients and did not rank scholarship candidates with AHP or Moora. In contrast, this article research makes an application program that is useful for assessing all prospective student scholarship recipients and then ranking the scholarship recipient candidates according to the criteria possessed by each candidate. scholarship grantee.

Anthony Anggrawan, Khasnur Hidjah, and Jihadil Qudsi S. (2017) implemented an application system to detect kidney failure [20]. The previous research and this article have similarities in realizing a computer application system using the PHP programming language and MySQL database. The difference is in the research methods and topics. Whereas in previous studies, it was related to the diagnosis of kidney disease using the CBR (CaseBased Reasoning) method, while in this study, it was related to scholarship recommendations using the Moora and AHP methods.

Andani et al. (2019) build a recommendation system for recipients of foundation scholarships 
using the Moora method. This previous research and the research in this article both developed a recommendation system for prospective scholarship recipients [17]. However, the previous study used the Moora method only, while the research in this article uses the Moora and AHP methods. The difference is also in the number of criteria that become a reference in providing recommendations for prospective scholarship recipients. The number of criteria in the previous study was only three: student academic index, parental income, and the number of dependents of students' parents. In comparison, the number of criteria in the research in this article there are six criteria, namely the student average academic index for the last two semesters, total achievement points inside and outside campus, a recommendation from the head of the study program, organizational activity, semester level, and other completeness of required documents.

Zaitun et al. (2019) implemented the Moora method for decision-making on recipients of financial assistance for Indonesian Smart Card participants [21]. This previous study determined the ranking of student candidates who received financial aid with eight prerequisite criteria: Smart Cards Recipient Status, Social Protection Card Recipient Status, Student Living Type, transportation used, Father's Occupation, and Mother's Occupation, Father's Income, and Mother's Income. In contrast to the research in this article, using the AHP and Moora methods in determining scholarship recipient candidates with six criteria as a ranking prerequisite. In addition, this article examines the accuracy of the method used in determining the ranking, which was not carried out in the previous research.

Chosy Yuda Sakti et al. (2019) ranked hospitals in serving public health with criteria for payment, prone road module, hospital registration, pharmacy model, inpatient, and emergency module [22]. This previous study used the average value of AHP and Moora's ranking (meaning that the two methods each stand alone in calculating the ranking, then each result is found for the average value). In contrast to the research in this article, ranking is carried out to determine scholarship recipients by combining the AHP and Moora methods with weighting using the AHP method and ranking using the Moora method. Besides that, the previous research did not test the ranking accuracy of the method used; meanwhile, the article in this study tested the ranking accuracy of the Moora method and a combination of the AHP and Moora methods.

Tasrif et al. (2021) developed an application to manage scholarships using the AHP method. In this previous study, five criteria requirements became a reference in determining the decision of scholarship recipients, namely academic index, achievement in the academic field, achievement in the non-academic field, the income of parents, and the number of dependents of parents. The similarity between the previous research and the research in this article is that both of them make computer applications to build a system for managing scholarship recipients. The difference is that the previous method used only one method, namely the AHP method, while in this study, two methods were used, namely the AHP method and the Moora method. Besides that, the difference between the previous research and this article research also lies in the criteria that become the requirements for scholarship recipients are not the same. In the research in this article, there are six criteria, namely the average achievement index value for the last two semesters, total achievement points inside and outside campus, a recommendation from the head of the study program, organizational activity, semester level, and other completeness of required documents.

Siregar, Tampubolon, Parapat, Malau, \& Hutagalung (2021) researched to select the most worthy students as scholarship recipients. This previous research used the Moora method and only used one criterion: the academic index value of students in recommending scholarship recipients [23]. In contrast to this article, the AHP method is used in addition to the Moora method. Besides, the study in this article uses not only one criterion but five other criteria besides the student's academic value criteria that are as a reference in recommending prospective scholarship recipients.

Eri Satria et al. (2021) researched the manual ranking of candidates for financial assistance via Indonesian Smart Cards using the AHP method [24]. However, unlike the research in this article, the results of the ranking of scholarship recipients by building a web-based computer application are not only the AHP method but a combination of the AHP and Moora methods. In addition, the criteria for determining candidates for receiving financial assistance differ between the previous research and this article.

In essence, this research has novelties that have not been studied by previous researchers in using the AHP method for weighting and the Moora method for ranking and the criteria used in determining the ranking. In addition, testing the method's accuracy in ranking scholarship recipients in this article is also a 
Table 1. Comparison of this article's work with some previous related works

\begin{tabular}{|c|c|c|c|c|c|c|c|c|}
\hline \multirow[t]{2}{*}{ Research by } & \multicolumn{2}{|c|}{$\begin{array}{l}\text { Research } \\
\text { methods }\end{array}$} & \multicolumn{2}{|r|}{ Criteria } & \multirow{2}{*}{$\begin{array}{l}\text { Build } \\
\text { apps }\end{array}$} & \multirow{2}{*}{$\begin{array}{c}\text { Accuracy } \\
\text { Test }\end{array}$} & \multirow{2}{*}{$\begin{array}{c}\text { Aid } \\
\text { fund }\end{array}$} & \multirow{2}{*}{$\begin{array}{l}\text { Weighting } \\
\text { and } \\
\text { Ranking }\end{array}$} \\
\hline & AHP & Moora & Number & Criteria name & & & & \\
\hline Russo \& Camanho & Yes & No & - & No mention & No & No & No & - \\
\hline Jibrin et al. & No & No & - & No mention & Yes & No & Yes & - \\
\hline Anthony Anggrawan et al. & No & No & 21 & Symptom of Kidney Failure & Yes & Yes & No & - \\
\hline Andani et al. (2019) & No & Yes & 3 & $\begin{array}{l}\text { Academic index, parental } \\
\text { income, and family dependents }\end{array}$ & No & No & Yes & - \\
\hline Zaitun et al. (2019) & No & Yes & 8 & $\begin{array}{l}\text { Smart Cards Recipient Status, } \\
\text { Social Protection Card } \\
\text { Recipient Status, Student Living } \\
\text { Type, Transportation used, } \\
\text { Father's Occupation, Mother's } \\
\text { Occupation, Father's Income, } \\
\text { and Mother's Income }\end{array}$ & No & No & Yes & - \\
\hline Chosy Yuda Sakti et al. & Yes & Yes & 6 & $\begin{array}{l}\text { Payment, Road Prone Modules, } \\
\text { Hospital Registration, Pharmacy } \\
\text { Model, Inpatient, and } \\
\text { Emergency Module }\end{array}$ & No & No & No & $\begin{array}{l}\text { Use the } \\
\text { average } \\
\text { value of } \\
\text { AHP and } \\
\text { Moora } \\
\text { rankings }\end{array}$ \\
\hline Tasrif et al. (2021) & Yes & No & 5 & $\begin{array}{l}\text { academic index, achievement in } \\
\text { the academic field, achievement } \\
\text { in the non-academic field, the } \\
\text { income of parents, and the } \\
\text { number of dependents of } \\
\text { parents }\end{array}$ & Yes & No & Yes & - \\
\hline Siregar et al. & No & Yes & 1 & academic index & & & Yes & - \\
\hline Eri Satria et al. & Yes & No & 5 & $\begin{array}{l}\text { average achievement index for } 3 \\
\text { courses, Indonesian Smart Card } \\
\text { participant, Parents' job, Parents' } \\
\text { Income, married or not married }\end{array}$ & No & No & Yes & - \\
\hline This (our) research & Yes & Yes & 6 & $\begin{array}{l}\text { achievement index for the last } \\
\text { two semesters, achievement } \\
\text { points inside and outside } \\
\text { campus, recommendation from } \\
\text { the head of the study program, } \\
\text { organizational activity, } \\
\text { semester level, and } \\
\text { completeness of documents }\end{array}$ & Yes & Yes & Yes & $\begin{array}{l}\text { Weighting } \\
\text { using AHP } \\
\text { while } \\
\text { ranking } \\
\text { using } \\
\text { Moora }\end{array}$ \\
\hline
\end{tabular}

novelty that other researchers have not done before (see Table 1). Table 1 shows a comparison of the differences between the work of this article and several previous related works.

The structure of the subsequent writing of this manuscript is as follows: the second part describes the Research Methodology, which includes explaining the programming language used in building the application system and the method used in recommending scholarship recipients. The third part discusses the research results and then ends by recapitulating the conclusions obtained from the research results, the novelty of the research, and suggestions for further study.

\section{Proposed method}

This research is a case study conducted at the STAHN (Sekolah Tinggi Agama Hindu Negeri) state tertiary education in Mataram, Indonesia. The number of prospective student scholarship recipients who became case studies in the ranking of scholarship recipients was 161 students. The programming language used is Visual Basic.Net or VB.Net, and the database used is MySQL.

MySQL is an open-source database system with the most users and is server-based [25]. VB.Net is a popular and superior visual programming language [26]. VB.Net is an event-based and object-oriented 


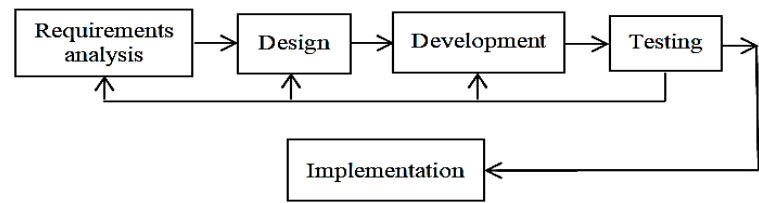

Figure. 1 Waterfall model of system development in this research

programming language $[27,28]$. VB.NET is suitable for interface embodiment and database building [28] [26]. Meanwhile, the development of an application system to provide recommendations for prospective scholarship recipients in this study uses the Waterfall model. The waterfall is a software development management model [29]. The sequence of phases in the Waterfall model is sequential from one stage to the following [30]. The development of a recommendation system for prospective scholarship recipients in this study is as shown in Fig. 1.

The requirements analysis stage is digging up the information needed (data retrieval) to develop the application system built. The design stage is an advanced stage of the Requirements Analysis stage. At this stage, the design of the application system development program in the form of a data flow diagram (DFD) and flowchart is realized. DFD is a diagram that describes the actors who enter data into the system and the system's primary users [31]. DFD also represents the flow of data from the built system, which is mainly used at the design stage [32]. In addition, DFD also presents the sequence of processes involved so that DFD is essential to achieve a structured system analysis [32]. The flowchart is an important part used at the development stage of any application system. Besides that, the flowchart describes the sequence of the application program process [33]. The development stage is the stage of realizing the developed application system. After the final stage of development, the application system testing stage is carried out whether it is following the desired needs. If something is not expected at this testing stage, improvements are made from the previous stage. The last stage is the implementation stage. At this stage, the system unit is integrated, and an application system implementation experiment is carried out to determine the reliability of the application system built. At the last stage, the accuracy of the application system was also tested.

\section{Result and discussion}

\subsection{Requirement analysis}

Based on the interviews conducted, it was revealed that six criteria became the requirements for considering prospective scholarship recipients. Table
Table 2. Interview result

\begin{tabular}{|c|c|}
\hline Interview Questions & Interview Answers \\
\hline $\begin{array}{l}\text { How does the } \\
\text { scholarship manager } \\
\text { recommend/predict } \\
\text { students who are } \\
\text { eligible for } \\
\text { scholarships? }\end{array}$ & $\begin{array}{l}\text { Management is still done } \\
\text { manually. }\end{array}$ \\
\hline $\begin{array}{l}\text { What are the criteria or } \\
\text { requirements that } \\
\text { prospective scholarship } \\
\text { recipients must } \\
\text { submit? }\end{array}$ & $\begin{array}{l}\text { Achievement index for the } \\
\text { last two semesters, a } \\
\text { recommendation from the } \\
\text { head of the study program, } \\
\text { year of college/semester, } \\
\text { certificate of achievement } \\
\text { ever obtained, active } \\
\text { organizational activities, } \\
\text { and supporting required } \\
\text { documents (registration } \\
\text { form, identity card, family } \\
\text { card, proof of paid tuition } \\
\text { fees, student identity card). }\end{array}$ \\
\hline $\begin{array}{l}\text { Which of these criteria } \\
\text { has the greatest } \\
\text { weight? }\end{array}$ & $\begin{array}{l}\text { Achievement index for the } \\
\text { last two semesters, total } \\
\text { activity points (calculated } \\
\text { based on the number of } \\
\text { certificates of achievement } \\
\text { obtained), a } \\
\text { recommendation from the } \\
\text { head of the study program, } \\
\text { activeness activities, } \\
\text { organizational al } \\
\text { year of college/semester } \\
\text { entry, and supporting } \\
\text { requirements documents. }\end{array}$ \\
\hline $\begin{array}{l}\text { Does the campus } \\
\text { scholarship } \\
\text { management } \\
\text { department have } \\
\text { difficulty in } \\
\text { recommending or } \\
\text { predicting students } \\
\text { who will receive } \\
\text { scholarships? }\end{array}$ & $\begin{array}{l}\text { Yes, it isn't easy because } \\
\text { of the many student } \\
\text { applicants, and the criteria } \\
\text { are quite a lot. }\end{array}$ \\
\hline $\begin{array}{l}\text { Does the scholarship } \\
\text { management } \\
\text { department need a } \\
\text { computer application } \\
\text { system that helps in } \\
\text { recommending } \\
\text { students who will } \\
\text { receive scholarships? }\end{array}$ & $\begin{array}{l}\text { Yes, so that the calculation } \\
\text { and ranking process can be } \\
\text { faster and more accurate. }\end{array}$ \\
\hline
\end{tabular}

2 shows the interview results from each interview question that has been carried out in collecting requirements analysis data.

The weight of the assessment of the six criteria is successive as follows: achievement index of the last two semesters of students, total activity points (calculated based on the number of certificates of 
Table 3. Criteria and the weight of each criterion

\begin{tabular}{|c|c|c|}
\hline Code & Criteria & Information \\
\hline $\mathrm{C} 1$ & $\begin{array}{l}\text { The average } \\
\text { cumulative } \\
\text { achievement of } \\
\text { academic index } \\
\text { score for the last } \\
\text { two semesters }\end{array}$ & $\begin{array}{l}\text { The range of these criteria } \\
\text { includes: Achievement index } \\
\text { less than } 2.50 \text {; The } \\
\text { achievement index is less } \\
\text { than } 3.00 \text { and greater than or } \\
\text { equal to } 2.50 \text {; The } \\
\text { achievement index is less } \\
\text { than } 3.50 \text { and greater than or } \\
\text { equal to } 3.00 \text {; and } \\
\text { Achievement index greater } \\
\text { than or equal to } 3.50\end{array}$ \\
\hline $\mathrm{C} 2$ & Total activity point & $\begin{array}{l}\text { The assessed activity's total } \\
\text { points are based on how } \\
\text { many achievements students } \\
\text { have achieved, both } \\
\text { internally and externally. The } \\
\text { range of the criteria used are: } \\
<50 ; 50-99 ; 100-149 ; 150 \\
-199 ; 200-249 ; 250-299 ; \\
\text { and }>300\end{array}$ \\
\hline C3 & $\begin{array}{l}\text { Letter of } \\
\text { recommendation }\end{array}$ & $\begin{array}{l}\text { This criterion is based on a } \\
\text { letter of recommendation } \\
\text { from the head of the study } \\
\text { program to students who are } \\
\text { eligible for scholarships. } \\
\text { Here is the range of these } \\
\text { criteria: (1) Have not a } \\
\text { recommendation; (2) Have a } \\
\text { recommendation }\end{array}$ \\
\hline $\mathrm{C} 4$ & $\begin{array}{l}\text { Organizational } \\
\text { activity }\end{array}$ & $\begin{array}{l}\text { This criterion is assessed } \\
\text { based on the student's } \\
\text { organizational activity. Here } \\
\text { is the range of these criteria: } \\
\text { Inactive and Active }\end{array}$ \\
\hline $\mathrm{C} 5$ & Semester & $\begin{array}{l}\text { On the criteria for the } \\
\text { semester level of students } \\
\text { being assessed, the } \\
\text { assessment ranges are as } \\
\text { follows: (1) Semester } 7 \text { or } 8 \text {; } \\
\text { (2) Semester } 5 \text { or } 6 \text {; (3) } \\
\text { Semester } 3 \text { or } 4 \text {; and (4) } \\
\text { Semester } 1 \text { or } 2\end{array}$ \\
\hline C6 & $\begin{array}{l}\text { Other completeness } \\
\text { of required } \\
\text { documents }\end{array}$ & $\begin{array}{l}\text { This criterion is in the form } \\
\text { of other documents required } \\
\text { for each prospective } \\
\text { scholarship recipient, } \\
\text { including the scholarship } \\
\text { application letter, statement } \\
\text { letter, registration form, } \\
\text { student identity card, } \\
\text { institutional fee payment, } \\
\text { identity card and family } \\
\text { card. The following is the } \\
\text { assessment range of these } \\
\text { criteria: Incomplete; } \\
\text { Complete enough; and } \\
\text { Complete }\end{array}$ \\
\hline
\end{tabular}

achievement obtained) students, letters of recommendation from the head of the study program, activeness of organizational activities from students, year of entry college/semester level of students, and other supporting requirements documents.

The interviews were obtained that manual scholarship management is complicated in determining prospective scholarship recipients because many applicants get student scholarships. Therefore, several criteria must be a reference in deciding student scholarship recipients accurately and quickly. Table 3 shows the criteria and weights of each criterion used in this study.

\subsection{Design}

The embodiment of the DFD of the application system to recommend prospective scholarship recipients is as shown in Fig. 2 and 3. The DFD level 0 (or context diagram) in Fig. 2 illustrates the relationship between external entities involved in the application system. Meanwhile, the DFD level 1 in Fig. 3 contains the core processes that exist in the system.

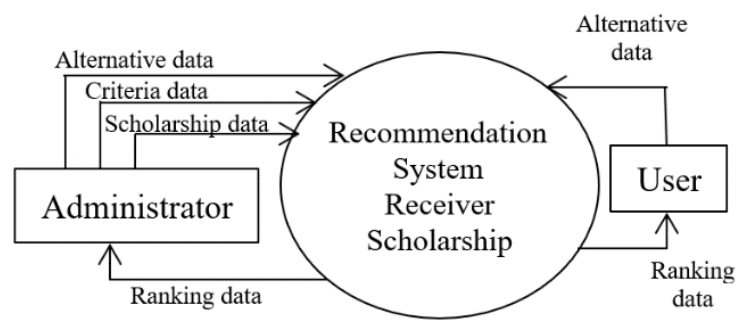

Figure. 2 DFD Level 0 of the scholarship recipients recommendation system

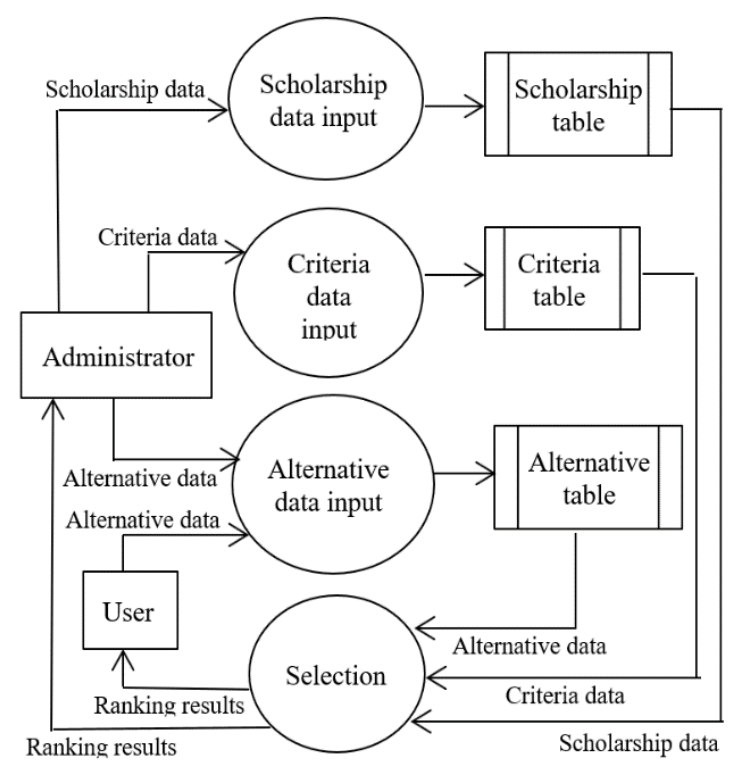

Figure. 3 DFD level 1 of the scholarship recipients recommendation system 


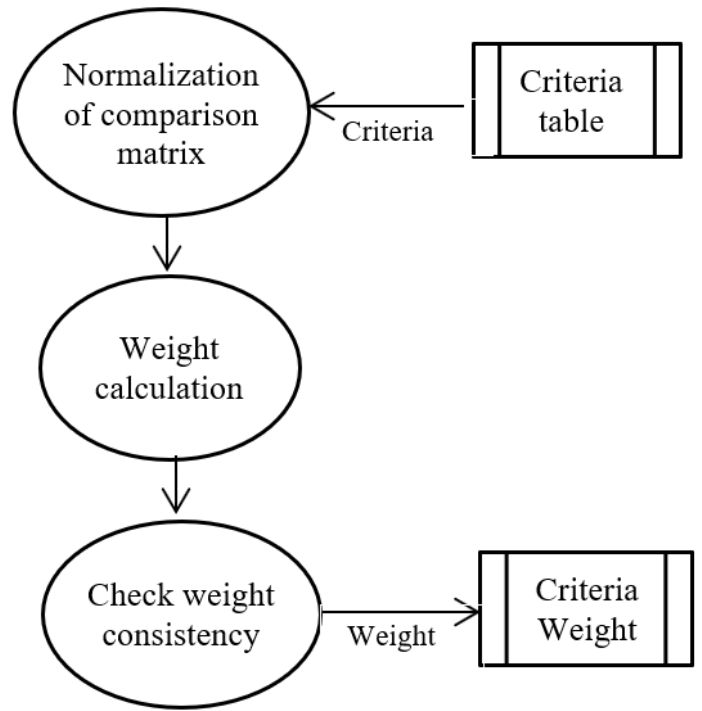

Figure. 4 DFD Level 2 AHP weighting process

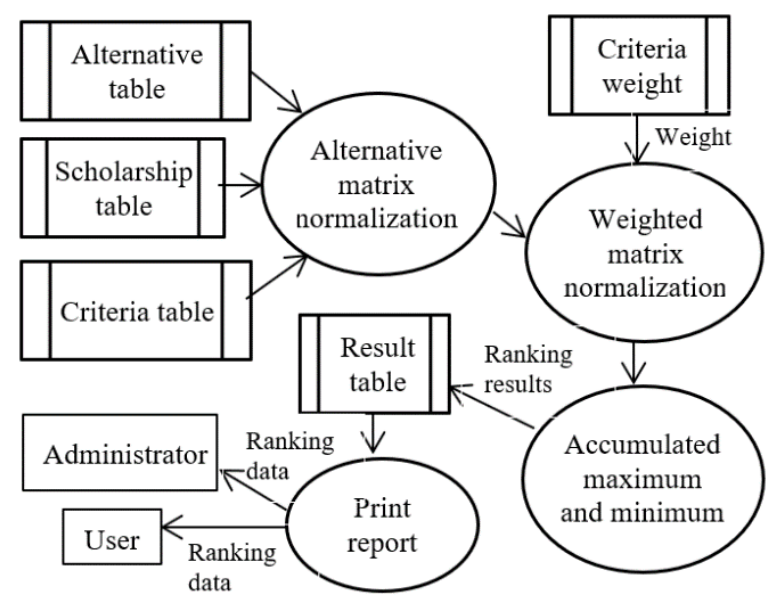

Figure. 5 DFD Level 3 moora ranking

DFD Level 2 (Fig. 4) describes the weighting process of AHP to see the consistency of the criteria data. Normalization of the comparison matrix with the initial value obtained from the criteria table where the realization of the results of normalization of the comparison matrix is by a weighting calculation process; The weighting results are checked for consistency in order to produce accurate values and can be continued to the Moora calculation stage.

Fig. 5 illustrates the flow or work steps of the Moora method in ranking, where the results of this ranking will be used as a report on the results of determining scholarship recipients. In this process, there are four processes that Normalizing Alternative Matrix carries out, Normalizing Weighted Matrix, Accumulating Max and Min Values, and Printing the results.

Alternative Matrix Normalization describes the process of normalizing the data, namely normalizing the uniformity of the values of each criterion into a dimension that has an interval (0.1). The alternative matrix normalization process comprises three tables: the alternative table, the scholarship table, and the criteria table. The alternative matrix normalization calculation results are obtained from the process of squaring of each scholarship criteria. Meanwhile, Weighted Matrix Normalization describes the weighting process from the Alternative Matrix Normalization process results, which is multiplied by the weight value for each criterion taken from the criteria weight table.

The accumulated maximum and minimum scores describe the calculation process to get the ranking results from scholarship recipients. However, the maximum value is obtained from the sum of the criteria values that benefit, while the minimum value is obtained from the sum of the cost values. After obtaining the maximum value and minimum value, the maximum value will be deducted from the minimum value. The result will be the basis for sorting or ranking; the highest value will be the first rank, and so on. The results of the accumulated maximum and minimum values are stored in the results table in the database file.

The print report process is the process of printing reports whose data is taken from the results table. The printing of this report displays the ranking results of prospective scholarship recipients, which are presented sequentially starting from the highest rank to the lowest rank.

The flowchart in Fig. 6 shows the ranking process, which starts with data collection. After the ranking process, the data preprocessing process is carried out at this stage, the data is processed, and invalid values will be deleted or changed so that the data becomes valid data for use in the following process. After preprocessing the data, the next stage is the weighting stage using the AHP method, and the results of this AHP method are in the form of the weights of each criterion. Finally, the weight of each of these criteria is used in the Moora method of ranking. The results of the Moora are in the form of ranking results from all criteria and alternatives.

\subsection{Development}

At the stage of the system development process, achievement scholarship registrant data, comparison scale and scholarship criteria data are processed to eliminate empty or null values so that the data can be processed. In carrying out the AHP and Moora process, it is necessary to determine the criteria from the basic requirements. The criteria used here are six criteria (C6). The assessment criteria used are as follows: $\mathrm{C} 1=$ average GPA in the last 2 semesters; 


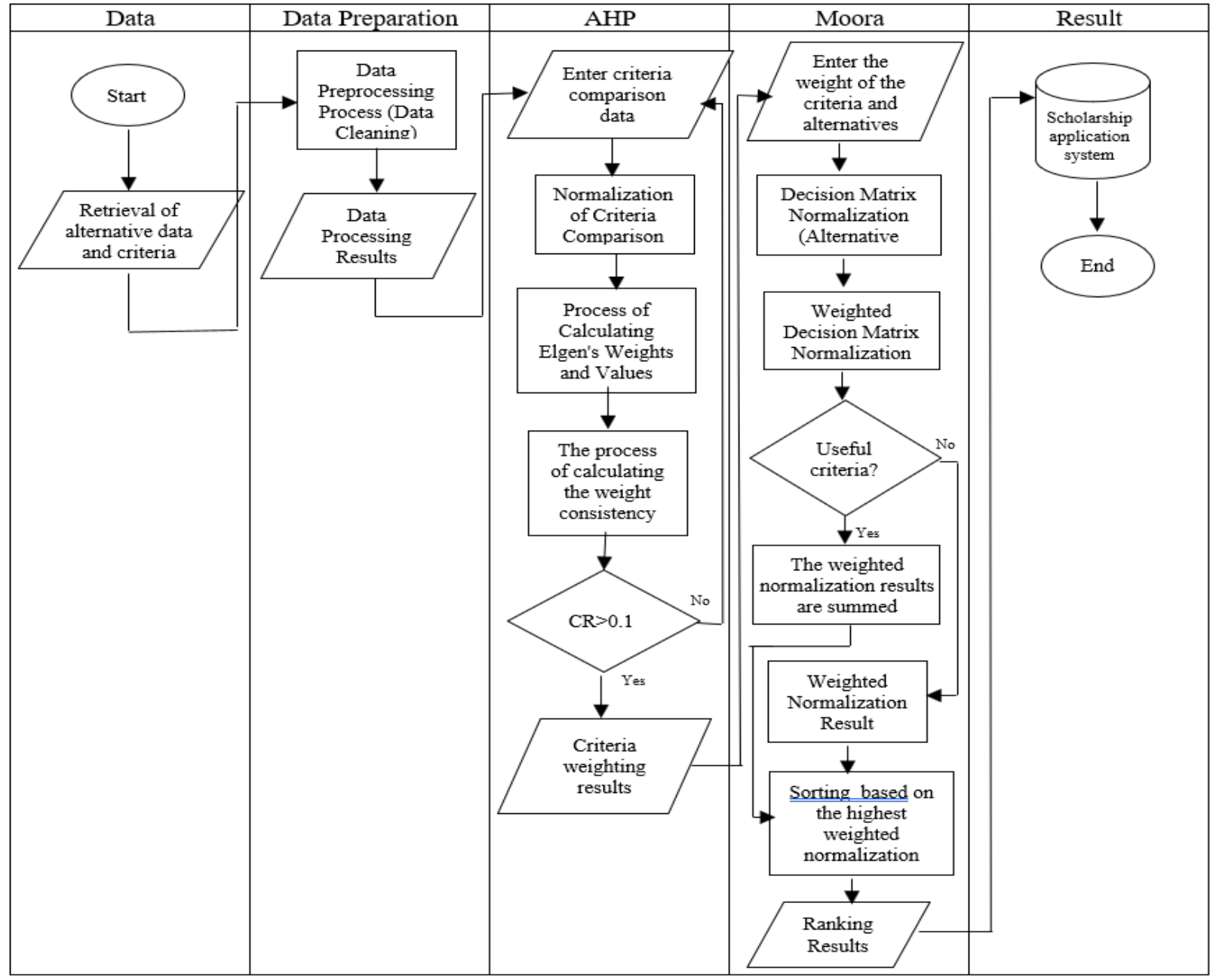

Figure. 6 Flowchart of the application system built

$\mathrm{C} 2=$ Total activity points; $\mathrm{C} 3=$ Letter of recommendation; $\mathrm{C} 4$ = Organizational activity; $\mathrm{C} 5=$ Semester; C6 = Completeness of required documents.

\subsubsection{Calculation with AHP}

\subsubsection{Comparison scale}

Table 4 shows a comparison scale as a determinant of the level of confidence in the prerequisites in applying for scholarships; the higher the level of importance, the greater the weight given, and when the requirements for submitting the level of importance are low, the value given is small.

\subsubsection{Create a pairwise comparison matrix for the criteria}

The scholarship requirement value is based on the criteria given as a prerequisite for applying for a scholarship. The value is obtained from the value of the comparison scale. The value given is based on the such as $\mathrm{C} 1$ requirements. Is it more important with C2 conditions? Apparently, C2 is three times more
Table 4. Comparison scale

\begin{tabular}{|c|l|l|}
\hline $\begin{array}{c}\text { Interest } \\
\text { level }\end{array}$ & \multicolumn{1}{|c|}{ Definition } & \multicolumn{1}{c|}{ Information } \\
\hline 1 & $\begin{array}{l}\text { Equally } \\
\text { important }\end{array}$ & $\begin{array}{l}\text { Both elements have the } \\
\text { same effect. }\end{array}$ \\
\hline 5 & $\begin{array}{l}\text { A little more } \\
\text { important }\end{array}$ & $\begin{array}{l}\text { Rating is slightly more in } \\
\text { favor of one element than } \\
\text { its partner }\end{array}$ \\
\hline 7 & More important & $\begin{array}{l}\text { The assessment is strongly } \\
\text { in favor of one element } \\
\text { compared to its partner. }\end{array}$ \\
\hline 9 & $\begin{array}{l}\text { One element is very } \\
\text { influential and its } \\
\text { dominance is evident. }\end{array}$ \\
\hline important & $\begin{array}{l}\text { It is evident that one } \\
\text { element is more important } \\
\text { than its partner at a high } \\
\text { level of confidence. }\end{array}$ \\
\hline $2,4,6,8$ & $\begin{array}{l}\text { The middle value } \\
\text { of the judgment } \\
\text { above }\end{array}$ & $\begin{array}{l}\text { This value is given if there } \\
\text { is doubt between two } \\
\text { adjacent ratings }\end{array}$ \\
\hline Opposite & $\begin{array}{l}\text { Aij = 1/ Aij (if for activity i gets one point } \\
\text { when compared to activity j then j has the } \\
\text { opposite value compared to i). }\end{array}$ \\
\hline
\end{tabular}


Table 5. Pairwise comparison matrix

\begin{tabular}{|c|c|c|c|c|c|c|}
\hline & $\mathrm{C} 1$ & $\mathrm{C} 2$ & $\mathrm{C} 3$ & $\mathrm{C} 4$ & $\mathrm{C} 5$ & $\mathrm{C} 6$ \\
\hline $\mathrm{C} 1$ & 1 & 3 & 3 & 5 & 5 & 7 \\
\hline $\mathrm{C} 2$ & $1 / 3$ & 1 & 1 & 3 & 3 & 5 \\
\hline $\mathrm{C} 3$ & $1 / 3$ & 1 & 1 & 3 & 3 & 5 \\
\hline $\mathrm{C} 4$ & $1 / 5$ & $1 / 3$ & $1 / 3$ & 1 & 1 & 3 \\
\hline $\mathrm{C} 5$ & $1 / 5$ & $1 / 3$ & $1 / 3$ & 1 & 1 & 3 \\
\hline $\mathrm{C} 6$ & $1 / 7$ & $1 / 5$ & $1 / 5$ & $1 / 3$ & $1 / 3$ & 1 \\
\hline
\end{tabular}

Table 6. Fractional numbers of pairwise comparison matrix

\begin{tabular}{|c|c|c|c|c|c|c|}
\hline & $\mathrm{C} 1$ & $\mathrm{C} 2$ & $\mathrm{C} 3$ & $\mathrm{C} 4$ & $\mathrm{C} 5$ & $\mathrm{C} 6$ \\
\hline C1 & 1.000 & 3.000 & 3.000 & 5.000 & 5.000 & 7.000 \\
\hline C2 & 0.333 & 1.000 & 1.000 & 3.000 & 3.000 & 5.000 \\
\hline C3 & 0.333 & 1.000 & 1.000 & 3.000 & 3.000 & 5.000 \\
\hline C4 & 0.200 & 0.333 & 0.333 & 1.000 & 1.000 & 3.000 \\
\hline C5 & 0.200 & 0.333 & 0.333 & 1.000 & 1.000 & 3.000 \\
\hline C6 & 0.142 & 0.200 & 0.200 & 0.333 & 0.333 & 1.000 \\
\hline
\end{tabular}

level of importance for the scholarship requirements, important than $\mathrm{C} 1$; then, the value is given three, as the results are presented in Table 5.

The results of the comparison matrix process are converted into fractional numbers to make it easier to calculate the next process, as presented in Table 6 .

\subsubsection{Normalizing each paired matrix value}

The next stage in the AHP calculation is to normalize by dividing each value in the column by the total value of each column. Table 7 shows the column sum results for each paired matrix value.

The next step is to find the results of matrix normalization with each column value in the pairwise comparison matrix divided by the total number of column values in the pairwise comparison matrix.

Table 8 is the result of normalization for each criterion based on the importance of the scholarship requirements.

Table 7. Total value in pairwise comparison matrix

\begin{tabular}{|c|c|c|c|c|c|c|}
\hline & $\mathrm{C} 1$ & $\mathrm{C} 2$ & $\mathrm{C} 3$ & $\mathrm{C} 4$ & $\mathrm{C} 5$ & $\mathrm{C} 6$ \\
\hline $\mathrm{C} 1$ & 1.000 & 3.000 & 3.000 & 5.000 & 5.000 & 7.000 \\
\hline C2 & 0.333 & 1.000 & 1.000 & 3.000 & 3.000 & 5.000 \\
\hline C3 & 0.333 & 1.000 & 1.000 & 3.000 & 3.000 & 5.000 \\
\hline C4 & 0.200 & 0.333 & 0.333 & 1.000 & 1.000 & 3.000 \\
\hline C5 & 0.200 & 0.333 & 0.333 & 1.000 & 1.000 & 3.000 \\
\hline C6 & 0.142 & 0.200 & 0.200 & 0.333 & 0.333 & 1.000 \\
\hline
\end{tabular}

\begin{tabular}{l|l|l|l|l|l|l} 
Total & 2.208 & 5.866 & 5.866 & 13.333 & 13.333 & 24.000
\end{tabular}

\subsubsection{Determining the average value of the criteria matrix}

To get the average value of the criteria matrix, it is by adding up the values of each row and dividing by the number of elements to get the priority value. Table 9 shows the results of the calculation of the average value of the criteria matrix that will be used to measure the consistency of the priority values (criteria weight).

\subsubsection{Finding the lambda $(\lambda)$ maximum (max) value that will be used to measure consistency}

The way to get the lambda $(\lambda)$ maximum (max) value is the column in the normalized matrix table multiplied by the average column in the priority value table.

Table 10 shows the result of measuring the consistency of the data used for the criteria for

Table 8. Normalized result matrix

\begin{tabular}{|c|c|c|c|c|c|c|}
\hline & C1 & C2 & C3 & C4 & C5 & C6 \\
\hline C1 & 0.453 & 0.511 & 0.511 & 0.375 & 0.375 & 0.292 \\
\hline C2 & 0.151 & 0.170 & 0.170 & 0.225 & 0.225 & 0.208 \\
\hline C3 & 0.151 & 0.170 & 0.170 & 0.225 & 0.225 & 0.208 \\
\hline C4 & 0.091 & 0.057 & 0.057 & 0.075 & 0.075 & 0.125 \\
\hline C5 & 0.091 & 0.057 & 0.057 & 0.075 & 0.075 & 0.125 \\
\hline C6 & 0.064 & 0.034 & 0.034 & 0.025 & 0.025 & 0.042 \\
\hline
\end{tabular}

Table 9. Priority value (criteria weight)

\begin{tabular}{|c|c|c|c|c|c|c|c|}
\hline & C1 & C2 & C3 & C4 & C5 & C6 & Average \\
\hline C1 & 0.453 & 0.511 & 0.511 & 0.375 & 0.375 & 0.292 & 0.420 \\
\hline C2 & 0.151 & 0.170 & 0.170 & 0.225 & 0.225 & 0.208 & 0.192 \\
\hline C3 & 0.151 & 0.170 & 0.170 & 0.225 & 0.225 & 0.208 & 0.192 \\
\hline C4 & 0.091 & 0.057 & 0.057 & 0.075 & 0.075 & 0.125 & 0.080 \\
\hline C5 & 0.091 & 0.057 & 0.057 & 0.075 & 0.075 & 0.125 & 0.080 \\
\hline C6 & 0.064 & 0.034 & 0.034 & 0.025 & 0.025 & 0.042 & 0.037 \\
\hline
\end{tabular}

Table 10. Lambda max value

\begin{tabular}{|c|c|c|c|c|c|c|c|c|}
\hline & $\mathrm{C} 1$ & $\mathrm{C} 2$ & C3 & $\mathrm{C} 4$ & C5 & C6 & $\begin{array}{l}\text { Ave } \\
\text { rage }\end{array}$ & $\lambda \operatorname{Max}$ \\
\hline \multirow{2}{*}{$\mathrm{C} 1$} & 0.45 & 0.51 & 0.51 & 0.37 & 0.37 & 0.29 & 0.42 & \multirow{2}{*}{2.63} \\
\hline & 3 & 1 & 1 & 5 & 5 & 2 & 0 & \\
\hline \multirow{2}{*}{$\mathrm{C} 2$} & 0.15 & 0.17 & 0.17 & 0.22 & 0.22 & 0.20 & 0.19 & \multirow{2}{*}{1.19} \\
\hline & 1 & 0 & 0 & 5 & 5 & 8 & 2 & \\
\hline \multirow{2}{*}{$\mathrm{C} 3$} & 0.15 & 0.17 & 0.17 & 0.22 & 0.22 & 0.20 & 0.19 & \multirow{2}{*}{1.19} \\
\hline & 1 & 0 & 0 & 5 & 5 & 8 & 2 & \\
\hline \multirow{2}{*}{$\mathrm{C} 4$} & 0.09 & 0.05 & 0.05 & 0.07 & 0.07 & 0.12 & 0.08 & \multirow{2}{*}{0.48} \\
\hline & 1 & 7 & 7 & 5 & 5 & 5 & 0 & \\
\hline \multirow{2}{*}{$\mathrm{C} 5$} & 0.09 & 0.05 & 0.05 & 0.07 & 0.07 & 0.12 & 0.08 & \multirow{2}{*}{0.48} \\
\hline & 1 & 7 & 7 & 5 & 5 & 5 & 0 & \\
\hline \multirow{2}{*}{ C6 } & 0.06 & 0.03 & 0.03 & 0.02 & 0.02 & 0.04 & 0.03 & \multirow{2}{*}{0.23} \\
\hline & 4 & 4 & 4 & 5 & 5 & 2 & 7 & \\
\hline
\end{tabular}


scholarship requirements by using the max. The max results will be used as a reference for the consistency of the criteria of the scholarship requirements.

\subsubsection{Measuring consistency}

To measure the consistency of the criterion value of the scholarship requirements using the formula: $C R=$ $C I / I R . \mathrm{CR}=$ Consistency Ratio; $\mathrm{CI}=$ Consistency Index; and IR = Random Index.

1. Calculate the value of $t$. The $t$-value is obtained by dividing the max value by each cell of the average value and adding then dividing by the number of criteria data.

$\mathrm{t}=(2.63 / 0.420)+(1.19 / 0.192)+(1.19 / 0.192)+$ $(0.48 / 0.080)+(0.48 / 0.080)+(0.23 / 0.037)$ $\mathrm{t}=6.1417$

2. Calculate the $\mathrm{CI}$ value. The $\mathrm{CI}$ value is obtained by using the formula: $C I=(t-n) /(n-1)$

Table 11. Scholarship recipients assessment matrix

\begin{tabular}{|c|c|c|c|c|c|c|c|}
\hline Code & Student Name & C1 & C2 & C3 & C4 & C5 & C6 \\
\hline A1 & & 4 & 2 & 2 & 2 & 3 & 2 \\
\hline A2 & Ida Ayu Putu & 4 & 2 & 2 & 2 & 1 & 3 \\
\hline A3 & Gta Pt. Lely & 4 & 1 & 2 & 2 & 4 & 2 \\
\hline A4 & Asmarani Pamela & 4 & 1 & 2 & 2 & 3 & 2 \\
\hline A5 & Ni Made Sri Dwi & 4 & 1 & 2 & 2 & 3 & 2 \\
\hline A6 & Ariani & 4 & 1 & 2 & 2 & 3 & 2 \\
\hline A7 & Ni Luh Ayu & 4 & 2 & 2 & 2 & 4 & 2 \\
\hline A8 & Ni Nyoman Ayu & 4 & 2 & 2 & 2 & 1 & 2 \\
\hline A9 & I Made Agus & 4 & 2 & 2 & 2 & 1 & 2 \\
\hline A10 & Ni Wayan Ayuni & 4 & 1 & 2 & 2 & 1 & 2 \\
\hline$\ldots .$. & $\ldots .$. & $\ldots$ & $\ldots$ & $\ldots$ & $\ldots$ & $\ldots$ & $\ldots$ \\
\hline$\ldots .$. & $\ldots$. & $\ldots$ & $\ldots$ & $\ldots$ & $\ldots$ & $\ldots$ & $\ldots$ \\
\hline A159 & Nengah Putra & 3 & 1 & 2 & 2 & 1 & 2 \\
\hline A160 & Dewa Komang & 3 & 1 & 2 & 2 & 1 & 2 \\
\hline A161 & Ni Wayan Sinta & 3 & 1 & 2 & 2 & 4 & 2 \\
\hline
\end{tabular}

Table 12. Normalized matrix results

\begin{tabular}{|c|c|c|c|c|c|c|c|}
\hline Code & Student Name & C1 & C2 & C3 & C4 & C5 & C6 \\
\hline A1 & I Wayan Suwira & 0.316 & 0.4 & 0.316 & 0.316 & 0.354 & 0.298 \\
\hline A2 & Ida Ayu Putu & 0.316 & 0.4 & 0.316 & 0.316 & 0.118 & 0.447 \\
\hline A3 & Gta Pt. Lely & 0.316 & 0.2 & 0.316 & 0.316 & 0.471 & 0.298 \\
\hline A4 & Asmarani Pamela & 0.316 & 0.2 & 0.316 & 0.316 & 0.354 & 0.298 \\
\hline A5 & Ni Made Sri Dwi & 0.316 & 0.2 & 0.316 & 0.316 & 0.354 & 0.298 \\
\hline A6 & Ariani & 0.316 & 0.2 & 0.316 & 0.316 & 0.354 & 0.298 \\
\hline A7 & Ni Luh Ayu & 0.316 & 0.4 & 0.316 & 0.316 & 0.471 & 0.298 \\
\hline A8 & Ni Nyoman Ayu & 0.316 & 0.4 & 0.316 & 0.316 & 0.118 & 0.298 \\
\hline A9 & I Made Agus & 0.316 & 0.4 & 0.316 & 0.316 & 0.118 & 0.298 \\
\hline A10 & Ni Wayan Ayuni & 0.316 & 0.2 & 0.316 & 0.316 & 0.118 & 0.298 \\
\hline$\ldots \ldots$ & $\ldots .$. & $\ldots .$. & $\ldots .$. & $\ldots .$. & $\ldots .$. & $\ldots .$. & $\ldots .$. \\
\hline$\ldots \ldots$ & $\ldots .$. & $\ldots .$. & $\ldots .$. & $\ldots .$. & $\ldots .$. & $\ldots .$. & $\ldots .$. \\
\hline A159 & Nengah Putra & 0.611 & 0.056 & 0.079 & 0.079 & 0.030 & 0.069 \\
\hline A160 & Dewa Komang & 0.611 & 0.056 & 0.079 & 0.079 & 0.029 & 0.069 \\
\hline A161 & Ni Wayan Sinta & 0.611 & 0.056 & 0.079 & 0.079 & 0.119 & 0.069 \\
\hline
\end{tabular}


$\mathrm{CI}=(6.1417-6) /(6-1)$

$\mathrm{CI}=0.022834$

3. Determine the IR value from the IR table based on many criteria data.

$\mathrm{IR}=1.24$

$\mathrm{CR}=0.022834 / 1.24=0.022856$

Status: Consistent

\subsubsection{Calculations with moora}

Based on the calculation of max, the resulting CR value is less than 0.1 , the weight of each criterion can be said to be consistent so that it can be continued for the Moora process.

Table 11 shows data on prospective scholarship recipients. The total data used in the manual calculation trial is 10 data on prospective scholarship recipients.

Table 13. Weighted normalized matrix

\begin{tabular}{|c|c|c|c|c|c|c|c|}
\hline Code & Student Name & C1 & C2 & C3 & C4 & C5 & C6 \\
\hline A1 & I Wayan Suwira & 0.133 & 0.077 & 0.061 & 0.025 & 0.028 & 0.011 \\
\hline A2 & Ida Ayu Putu & 0.133 & 0.077 & 0.061 & 0.025 & 0.009 & 0.017 \\
\hline A3 & Gta Pt. Lely & 0.133 & 0.038 & 0.061 & 0.025 & 0.038 & 0.011 \\
\hline A4 & Asmarani Pamela & 0.133 & 0.038 & 0.061 & 0.025 & 0.028 & 0.011 \\
\hline A5 & Ni Made Sri Dwi & 0.133 & 0.038 & 0.061 & 0.025 & 0.028 & 0.011 \\
\hline A6 & Ariani & 0.133 & 0.038 & 0.061 & 0.025 & 0.028 & 0.011 \\
\hline A7 & Ni Luh Ayu & 0.133 & 0.077 & 0.061 & 0.025 & 0.038 & 0.011 \\
\hline A8 & Ni Nyoman Ayu & 0.133 & 0.077 & 0.061 & 0.025 & 0.009 & 0.011 \\
\hline A9 & I Made Agus & 0.133 & 0.077 & 0.061 & 0.025 & 0.009 & 0.011 \\
\hline A10 & Ni Wayan Ayuni & 0.133 & 0.038 & 0.061 & 0.025 & 0.009 & 0.011 \\
\hline$\ldots \ldots$ & $\ldots .$. & $\ldots .$. & $\ldots .$. & $\ldots .$. & $\ldots .$. & $\ldots .$. & $\ldots .$. \\
\hline$\ldots .$. & $\ldots . .$. & $\ldots .$. & $\ldots .$. & $\ldots .$. & $\ldots .$. & $\ldots .$. & $\ldots .$. \\
\hline A159 & Nengah Putra & 0.032 & 0.15 & 0.140 & 0.006 & 0.010 & 0.002 \\
\hline A160 & Dewa Komang & 0.032 & 0.15 & 0.140 & 0.006 & 0.002 & 0.002 \\
\hline A161 & Ni Wayan Sinta & 0.032 & 0.15 & 0.140 & 0.006 & 0.010 & 0.002 \\
\hline
\end{tabular}

Table 14. Maximum and minimum value

\begin{tabular}{|c|c|c|c|c|}
\hline Code & Student Name & $\begin{array}{c}\text { Maximum } \\
\text { Value }\end{array}$ & Minimum value & $\mathbf{Y i}$ \\
\hline A1 & I Wayan Suwira & 0.335 & 0 & 0.335 \\
\hline A2 & Ida Ayu Putu & 0.321 & 0 & 0.321 \\
\hline A3 & Gta Pt. Lely & 0.306 & 0 & 0.306 \\
\hline A4 & Asmarani Pamela & 0.296 & 0 & 0.296 \\
\hline A5 & Ni Made Sri Dwi & 0.296 & 0 & 0.296 \\
\hline A6 & Ariani & 0.296 & 0 & 0.296 \\
\hline A7 & Ni Luh Ayu & 0.344 & 0 & 0.344 \\
\hline A8 & Ni Nyoman Ayu & 0.316 & 0 & 0.316 \\
\hline A9 & I Made Agus & 0.316 & 0 & 0.16 \\
\hline A10 & Ni Wayan Ayuni & 0.277 & 0 & 0.277 \\
\hline$\ldots \ldots$. & $\ldots .$. & $\ldots .$. & $\ldots .$. & $\ldots .$. \\
\hline$\ldots .$. & $\ldots .$. & $\ldots .$. & $\ldots .$. & $\ldots .$. \\
\hline A159 & Nengah Putra & 0.072 & 0 & 0.072 \\
\hline A160 & Dewa Komang & 0.072 & 0 & 0.072 \\
\hline A161 & Ni Wayan Sinta & 0.079 & 0 & 0.079 \\
\hline & & & & \\
\hline
\end{tabular}


The calculation process with Moora is as follows:

- Create a normalized decision matrix using the Moora method. The formula used to create a normalized matrix is:

$$
X i j=\frac{X i j}{\sqrt{\sum_{j=1}^{m} x_{i j}^{2}}}
$$

$X i j$ is a dimension value with an interval of [0, 1] representing the alternative normalization result $i$ on the $j$ th attribute. Table 12 is the result of the normalization of scholarship applicant data.

- Create a weighted normalized matrix:

This stage is the weighted normalization stage using the priority weights that have been obtained

Using the AHP method in Table 9. The way to create a weighted normalized matrix is that the results in the Moora normalization table are multiplied by the priority weight value to produce a weighted normalized matrix value, as shown in Table 13 .

Table 13 is the result of the weighted normalized matrix process. The results of the weighted normalization process are used to find the maximum and minimum values.

- Finding the maximum and minimum values for each alternative.

The maximum value is obtained from the sum of the criteria that are beneficial in the weighted normalized matrix, while the minimum value is obtained from the sum of the criteria that are costly in the weighted normalized matrix. Table 14 results from the search calculation of the minimummaximum value where the minimum value is 0 because each criterion is a benefit.

- Finding the maximum and minimum values for each alternative.

To get the final value of the Moora process (as shown in Table 15) is to reduce the maximum value with the minimum value.

In the next stage, the process of finding the final value is sorting the data based on the Yi value in Table 15 to get the final result or ranking results.

Table 16 is the result of the ranking process of the Moora results sorted from the largest to the smallest value. The order of ranking scholarship recipients from the top to the lower ranking is I Wayan Suwira. Ida Ayu Putu, Gta Pt. Lely, Asmarani Pamela, Ni Made Sri Dwi, Ariani, Ni Luh Ayu, Ni Nyoman Ayu, and so on.

\subsubsection{Calculations with Moora}

The ranking results using the combined AHP and Moora methods are shown in Table 17.

The number of available scholarship quotas is 135 scholarships, which is smaller than the number of prospective scholarship participants, which amounted to 161 candidates. So it is necessary to screen prospective scholarship participants so that only 135 students get scholarships. This study tested the accuracy of the Moora method and a combination of the AHP and Moora methods to find out which

Table 15. Final value matrix

\begin{tabular}{|c|c|c|c|c|}
\hline Code & Student Name & $\begin{array}{c}\text { Maximum } \\
\text { Value }\end{array}$ & Minimum value & Yi \\
\hline A1 & I Wayan Suwira & 0.335 & 0 & 0.335 \\
\hline A2 & Ida Ayu Putu & 0.321 & 0 & 0.321 \\
\hline A3 & Gta Pt. Lely & 0.306 & 0 & 0.306 \\
\hline A4 & Asmarani Pamela & 0.296 & 0 & 0.296 \\
\hline A5 & Ni Made Sri Dwi & 0.296 & 0 & 0.296 \\
\hline A6 & Ariani & 0.296 & 0 & 0.296 \\
\hline A7 & Ni Luh Ayu & 0.344 & 0 & 0.344 \\
\hline A8 & Ni Nyoman Ayu & 0.316 & 0 & 0.316 \\
\hline A9 & I Made Agus & 0.316 & 0 & 0.16 \\
\hline A10 & Ni Wayan Ayuni & 0.277 & 0 & 0.277 \\
\hline$\ldots \ldots$. & $\ldots .$. & $\ldots .$. & $\ldots .$. & $\ldots .$. \\
\hline$\ldots \ldots$ & $\ldots .$. & $\ldots .$. & $\ldots .$. & $\ldots .$. \\
\hline A159 & Nengah Putra & 0.072 & 0 & 0.072 \\
\hline A160 & Dewa Komang & 0.072 & 0 & 0.072 \\
\hline A161 & Ni Wayan Sinta & 0.079 & 0 & 0.079 \\
\hline
\end{tabular}


Table 16. Ranking matrix

\begin{tabular}{|c|c|c|}
\hline Code & Student Name & Value \\
\hline A1 & I Wayan Suwira & 0.102 \\
\hline A2 & Ida Ayu Putu & 0.099 \\
\hline A3 & Gta Pt. Lely & 0.089 \\
\hline A4 & Asmarani Pamela & 0.087 \\
\hline A5 & Ni Made Sri Dwi & 0.087 \\
\hline A6 & Ariani & 0.105 \\
\hline A7 & Ni Luh Ayu & 0.098 \\
\hline A8 & Ni Nyoman Ayu & 0.098 \\
\hline A9 & I Made Agus & 0.082 \\
\hline A10 & Ni Wayan Ayuni & 0.105 \\
\hline$\ldots \ldots$ & $\ldots . .$. & $\ldots \ldots$ \\
\hline$\ldots \ldots$ & $\ldots . .$. & $\ldots \ldots$ \\
\hline A159 & Nengah Putra & 0.072 \\
\hline A160 & Dewa Komang & 0.072 \\
\hline A161 & Ni Wayan Sinta & 0.079 \\
\hline
\end{tabular}

Table 17. System ranking results moora and AHP

\begin{tabular}{|c|c|c|c|}
\hline No. & Ranking & Student Name & Value \\
\hline 1 & 1 & I Made Kavin Pradipa & 0,1065496 \\
\hline 2 & 2 & Ni Putu Virgi Eka Ayu Rasta & 0,1052412 \\
\hline 3 & 2 & Dewa Nyoman Mayuradana & 0,1052412 \\
\hline 4 & 2 & Ni Luh Ayu & 0,1052412 \\
\hline 5 & 2 & I Gede Putra & 0,1052412 \\
\hline 6 & 2 & Dewayu Paramita Ari Utami & 0,1052412 \\
\hline 7 & 2 & Ni Luh Ayu Puniawati & 0,1052412 \\
\hline 8 & 2 & Ni Nengah Mega Juniarsini & 0,1052412 \\
\hline 9 & 2 & Ni Wayan Noviyanti & 0,1052412 \\
\hline 10 & 3 & Komang Dewi Patmini & 0,1041529 \\
\hline$\ldots \ldots$ & $\ldots \ldots$ & $\ldots .$. & $\ldots .$. \\
\hline$\ldots \ldots$ & $\ldots \ldots$ & $\ldots$. & $\ldots$. \\
\hline A159 & 27 & Nengah Putra & 0,0722262 \\
\hline A160 & 27 & Dewa Komang & 0,0722262 \\
\hline A161 & 27 & Ida Ayu Tamara Nandini & 0,0722262 \\
\hline
\end{tabular}

method is more effective or more accurate in ranking candidate participants. As a note, the accuracy test of AHP and Moora methods has never been done by previous related works (see Table 1). The method that has better accuracy will be applied in the development of the application program that is built. The test is carried out based on actual data of scholarship recipients obtained from case study data with the existing criteria and weight values. The formula used to calculate accuracy is the confusion matrix test with the formula:

$$
\text { Accuracy }=\frac{(T P+T N)}{(T P+F P+F N+T N)}
$$

Notes:

$\mathrm{TP}=$ True Positive $; \mathrm{TN}=$ True Negative $; \mathrm{FP}=$ False Positive; and FN = False Negative.
Table 18. The predicted value of the actual data and the ranking results in using the Moora and AHP methods

\begin{tabular}{|c|c|c|}
\hline \multirow{2}{*}{ Predicted Value } & \multicolumn{2}{|c|}{ Actual Data } \\
\cline { 2 - 3 } & Positive & Negative \\
\hline Data True & $\mathrm{TP}=127$ & $\mathrm{FP}=8$ \\
\hline Data False & $\mathrm{FN}=0$ & $\mathrm{TN}=0$ \\
\hline
\end{tabular}

Table 19. The predicted value of the actual data and the ranking results in using the Moora method

\begin{tabular}{|c|c|c|}
\hline \multirow{2}{*}{$\begin{array}{c}\text { Predicted } \\
\text { Value }\end{array}$} & \multicolumn{2}{|c|}{ Data actual } \\
\cline { 2 - 3 } & Positive & Negative \\
\hline Data True & $\mathrm{TP}=121$ & $\mathrm{FN}=14$ \\
\hline Data False & $\mathrm{FP}=0$ & $\mathrm{TN}=0$ \\
\hline
\end{tabular}

Recommendation Accuracy with Moora and $\mathrm{AHP}=(\mathrm{TP}+\mathrm{TN}) /(\mathrm{TP}+\mathrm{FP}+\mathrm{FN}+\mathrm{TN})=(127+$ $0) /(127+0+8+0)=127 / 135=0,9407($ See Table 18). Or if expressed in percent, the accuracy of the recommendation with Moora and AHP is $94.7 \%$. 
Table 20. Scholarship recipients recommendation

\begin{tabular}{|c|c|c|}
\hline Method & $\begin{array}{c}\text { Amount } \\
\text { of data }\end{array}$ & $\begin{array}{c}\text { Result } \\
\text { Accuracy }\end{array}$ \\
\hline $\begin{array}{l}\text { Analytical Hierarchy } \\
\text { Process (AHP) and } \\
\text { Multi-Objective } \\
\text { Optimization based on } \\
\text { Ratio Analysis (Moora) }\end{array}$ & 135 & $94.07 \%$ \\
\hline $\begin{array}{l}\text { Multi-Objective } \\
\text { Optimization on the } \\
\text { basis of Ratio Analysis } \\
\text { (Moora) }\end{array}$ & 135 & $89,62 \%$ \\
\hline
\end{tabular}

Recommendation Accuracy with Moora $=(\mathrm{TP}+$ $\mathrm{TN}) /(\mathrm{TP}+\mathrm{FP}+\mathrm{FN}+\mathrm{TN})=(121+0) /(121+0+$ $14+0)=121 / 135=0,896($ See Table 19). Or if expressed in percent, the accuracy of the recommendation with Moora is $89.6 \%$.

Based on the calculation results, it is found that the accuracy generated in providing recommendations for scholarship recipients using the Moora and AHP methods is $94.07 \%$.

Table 20 shows a comparison of the accuracy between the Moora method and the combination of the Moora and AHP methods in providing recommendations for scholarship recipients.

Referring to the trial use of the application program built in this study, it shows that: determination of scholarship recipients using an application program created by applying a combination of the Moora and AHP methods takes work time only on entering data into a computer (2 working days). Meanwhile, determining the ranking of scholarship recipient candidates using the built application program requires less than one minute processing time. In contrast, manual or semi-manual work for scholarship recipients who have a better ranking of requirements takes time to complete not only in data typing but sorting out and choosing a better ranking takes more than two weeks of working time. It means that selecting candidates who receive scholarships according to better eligibility as much as the available quota takes a shorter time than manual or semi-manual processing with the help of a spreadsheet application program. In addition, the accuracy of the ranking results for scholarship recipients does not raise any doubt for the officeholders, considering that the computer work process has very high accuracy.

\section{Conclusion}

Developing an application system integrated with the database to provide recommendations for prospective scholarship recipients makes the ranking process faster and more accurate. The combination of the AHP and Moora methods in recommending eligible scholarship recipients based on the criteria for prospective scholarship recipients is more accurate (up to 94,07\%) when compared to using only one Moora method (whose accuracy is only $89.62 \%$ ). In addition, the selection of prospective scholarship recipients following better eligibility as much as the available quota by using the built application program helps speed up the completion of the determination of the ranking of prospective scholarship recipients compared to the manual process. In addition, the accuracy of the results related to the ranking of scholarship recipients does not doubt its accuracy for officeholders.

The novelty of the results of this study is to use a combination of two methods (AHP and Moora) and criteria items in the ranking process that has never been done by other studies before. In addition, this study examines the accuracy of the methods used in ranking scholarship recipients, which is another novelty of this research that previous researchers have never done.

This research was conducted using a combination of AHP and Moora methods in recommending prospective student scholarship recipients; therefore, it is necessary to carry out further research for other cases and various methods.

\section{Conflicts of Interest}

The authors declare no conflict of interest.

\section{Author Contributions}

The first author carried out research background, research analysis and comparison of results with previous works, and conclusions including supporting references. The second author has carried out data collection and completed the necessary calculations, including calculating the accuracy of the results of the research method. The third author has worked on editing and visualization, including creating and testing application programs. Finally, the fourth author re-checked the manuscript's contents, including the writing.

\section{References}

[1] A. Anggrawan, "Percentage of Effect of Blended Learning Madel on Learning Outcome", In: Proc. of International Conf. On Informatics and Computing, 2019.

[2] P. Beneito, J. E. Boscá, and J. Ferri, "Tuition fees and student effort at university", Economics 
of Education Review., Vol. 64, No. June, pp. 114-128, 2018.

[3] K. Czarnecki, T. Korpi, and K. Nelson, "Student support and tuition fee systems in comparative perspective", Studies in Higher Education., Vol. 46, No. 11, pp. 2152-2166, 2020.

[4] S. Dynarski and J. S. Clayton, "Financial Aid Policy: Lessons from Research", The Future of Children., Vol. 23, No. 1, pp. 67-91, 2013.

[5] M. A. Jibrin, M. N. Musa, and S. Tahir, "Development of E-Scholarship System", International Journal of Computer Science and Information Technologies., Vol. 7, No. 2, pp. 523-530, 2016.

[6] N. M. Ganem and M. Manasse, "The Relationship between Scholarships and Student Success: An Art and Design Case Study", Education Research International., Vol. 2011, pp. 1-8, 2011.

[7] D. L. Martínez and S. Brusoni, "Cognitive Flexibility and Adaptive Decision-Making: Evidence from a laboratory study of expert decision-makers", Strategic Management Journal., Vol. 39, No. 4, pp. 1031-1058, 2018.

[8] P. H. D. Santos, S. M. Neves, D. O. Sant'Anna, C. H. D. Oliveira, and H. D. Carvalho, "The analytic hierarchy process supporting decision making for sustainable development: An overview of applications", Journal of Cleaner Production., Vol. 212, pp. 119-138, 2019.

[9] T. D. Puspitasari, E. O. Sari, P. Destarianto, and H. Y. Riskiawan, "Decision Support System for Determining Scholarship Selection using an Analytical Hierarchy Process", In: Proc. of The 2nd International Joint Conference on Science and Technology 2017, 2018, No. 11, pp. 61-67, 2017.

[10] R. D. F. S. M. Russo and R. Camanho, "Criteria in AHP: A systematic review of literature", Procedia Computer Science., Vol. 55, No. Itqm, pp. 1123-1132, 2015.

[11] E. Tasrif, H. K. Saputra, D. Kurniadi, H. Hidayat, and A. Mubai, "Designing Website-Based Scholarship Management Application for Teaching of Analytical Hierarchy Process (AHP) in Decision Support Systems (DSS) Subjects", International Journal of Interactive Mobile Technologies., Vol. 15, No. 9, pp. 179191, 2021.

[12] V. Acharya, S. K. Sharma, and S. K. Gupta, "Analyzing the factors in industrial automation using analytic hierarchy process", Computers \& Electrical Engineering., Vol. 71, No. October, pp. 877-886, 2018.
[13] K. Arai, "Extraction of Keywords for Retrieval from Paper Documents and Drawings based on the Method of Determining the Importance of Knowledge by the Analytic Hierarchy Process: AHP”, International Journal of Advanced Computer Science and Applications., Vol. 11, No. 10, pp. 48-55, 2020.

[14] A. S. Baswaraj, M. S. Rao, and P. J. Pawar, "Application of AHP for process parameter selection and consistency verification in secondary steel manufacturing", In: Proc. of Materials Today: Proceedings, Vol. 5, No. 13, pp. 27166-27170, 2018.

[15] P. Karande and S. Chakraborty, "Application of multi-objective optimization on the basis of ratio analysis (Moora) method for materials selection", Materials \& Design., Vol. 37, No. 2012, pp. 317-324, 2012.

[16] W. K. M. Brauers, E. K. Zavadskas, F. Peldschus, and Z. Turskis, "Multi-Objective Optimization of Road Design Alternatives with an Application of the Moora Method", In: Proc. of the 25th International Symposium on Automation and Robotics in Construction, No. June, pp. 1-9, 2008.

[17] S. R. Andani, Poningsih, W. Saputra, M. R. Lubis, I. Damanik, K. N. A. Nur, and R. F. Sinaga, "Application of the Moora Method for Decision Making in Receiver Foundation Scholarship in AMIK Tunas Bangsa", Journal of Physics Conference Series., Vol. 1255, No. 1, pp. 1-7, 2019.

[18] V. Gadakh, "Application of Moora method for parametric optimization of milling process", International Journal of Applied Engineering Research., Vol. 1, No. 4, pp. 743-758, 2011.

[19] U. K. Mandal and B. Sarkar, "Selection of Best Intelligent Manufacturing System (IMS) Under Fuzzy Moora Conflicting MCDM Environment", International Journal of Emerging Technology and Advanced Engineering., Vol. 2, No. 9, pp. 301-310, 2012.

[20] A. Anggrawan, K. Hidjah, and Q. S. Jihadil, "Kidney failure diagnosis based on case-based reasoning (CBR) method and statistical analysis", In: Proc. of 2016 International Conference on Informatics and Computing, pp. 298-303, 2016.

[21] Zaitun, Mustakim, I. Kamila, and S. S. Helma, "Implementation of MOORA Method for Determining Prospective Smart Indonesia Program Funds Recipients", International Journal of Engineering and Advanced Technology, Vol. 9, No. 2, pp. 1922-1925, 2019. 
[22] C. Y. Sakti, K. R. Sungkono, and R. Sarno, "Determination of hospital rank by using Analytic Hierarchy Process (AHP) and Multi Objective Optimization on the Basis of Ratio Analysis (MOORA)", In: Proc. of 2019 Int. Semin. Appl. Technol. Inf. Commun. Ind. 4.0 Retrosp. Prospect. Challenges, iSemantic 2019, pp. 178-183, 2019.

[23] V. M. M. Siregar, M. R. Tampubolon, E. P. S. Parapat, E. I. Malau, and D. S. Hutagalung, "Decision support system for selection technique using Moora method", In: Proc. of IOP Conference Series: Materials Science and Engineering, Vol. 1088, No. 1, pp. 1-6, 2021.

[24] E. Satria, D. N. Ilham, A. Budiansyah, R. A. Candra, and M. Papuangan, "Recommendations for Candidates for KIP-Kuliah Recipients Using AHP and Borda Methods on Group Decision Support Systems", Journal of Computer Networks, Architecture and High Performance Computing., Vol. 3, No. 2, pp. 249-255, 2021.

[25] A. Anggrawan, N. Ibrahim, S. Muslim, and C. Satria, "Interaction between Learning Style and Gender in Mixed Learning with 40 \% Face-toface Learning and $60 \%$ Online Learning", International Journal of Advanced Computer Science and Applications., Vol. 10, No. 5, pp. 407-413, 2019.

[26] A. Anggrawan, C. Satria, N. Gusti, and A. Dasriani, "Reciprocity Effect between Cognitive Style and Mixed Learning Method on Computer Programming Skill", Journal of Computer Science., Vol. 17, No. 9, pp. 814-824, 2021.

[27] D. Yindi, "Visual Basic Program Designing Based on Computational Thinking Capabilities Training", In: Proc. of 2nd Information Technology and Mechatronics Engineering Conference, pp. 175-178, 2016.

[28] K. A. Othman, M. A. H. M. Isa, M. A. Baharuddin, M. A. Ghazali, Z. I. Khan, and N. A. Zakaria, "Forest Monitoring System Implementation using Visual Basic and Android Application", In: Proc. of 18th International Symposium on Communication and Information Technology, No. 600, pp. 447-451, 2018.

[29] A. M. Dima and M. A. Maassen, "From waterfall to agile software: Development models in the IT sector, 2006 to 2018. impacts on company management", Journal of International Studies., Vol. 11, No. 2, pp. 315326, 2018.

[30] Y. Bassil, "A Simulation Model for the Waterfall Software Development Life Cycle", International Journal of Engineering \&
Technology., Vol. 2, No. 05, pp. 3823-3830, 2012.

[31] R. Ibrahim and S. Y. Yen, "Formalization of the Data Flow Diagram Rules for Consistency Check", International Journal of Software Engineering \& Applications, Vol. 1, No. 4, pp. 95-111, 2010.

[32] J. P. Coleman, "Data Flow Sequences: A Revision of Data Flow Diagrams for Modelling Applications using XML", International Journal of Advanced Computer Science and Applications., Vol. 4, No. 5, pp. 28-31, 2013.

[33] A. Anggrawan, N. Ibrahim, M. Suyitno, and C. Satria, "Influence of Blended Learning on Learning Result of Algorithm and Programming", In: Proc. of Third International Conf. On Informatics and Computing, pp. 1-6, 2018. 